Provided for non-commercial research and education use. Not for reproduction, distribution or commercial use.

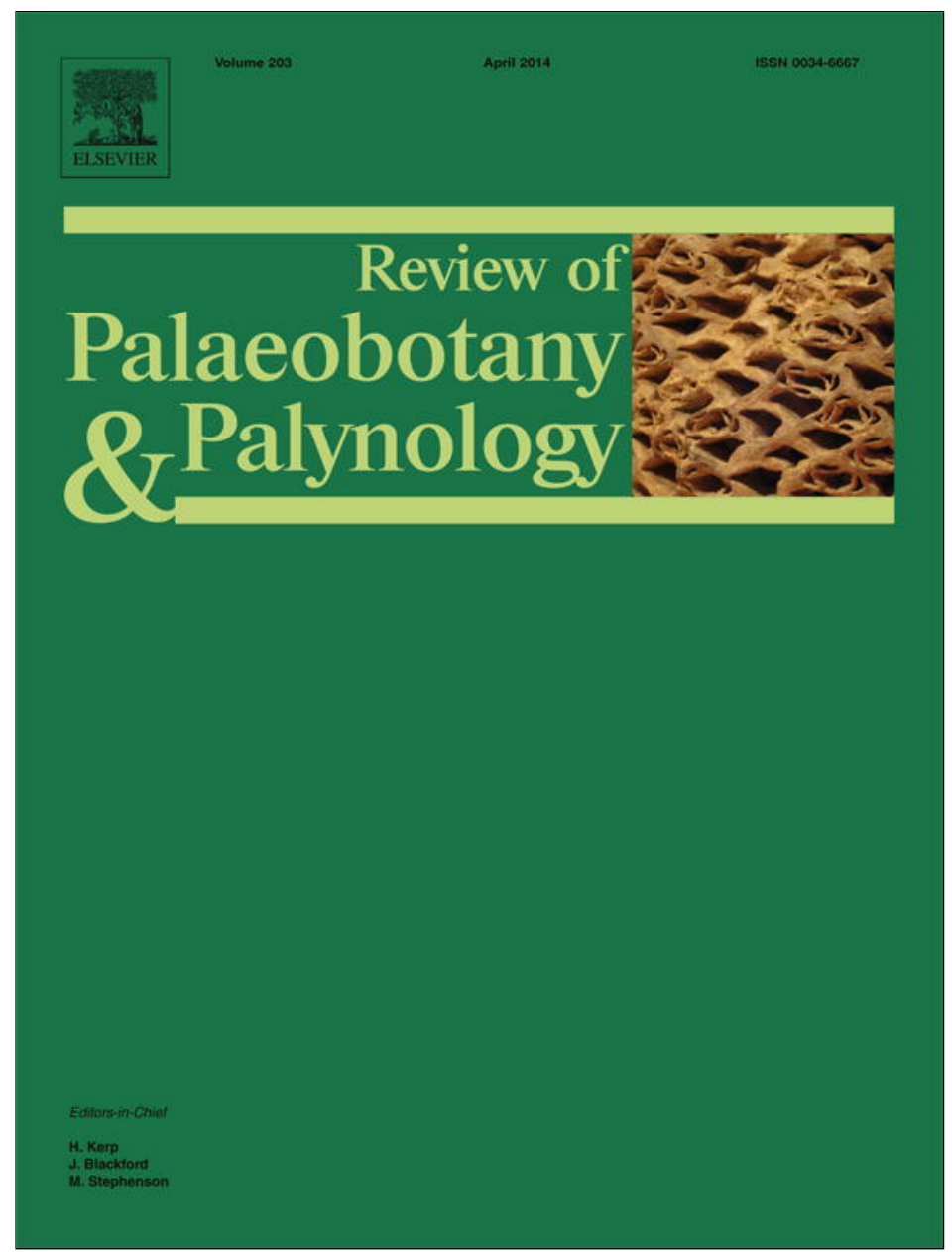

This article appeared in a journal published by Elsevier. The attached copy is furnished to the author for internal non-commercial research and education use, including for instruction at the authors institution and sharing with colleagues.

Other uses, including reproduction and distribution, or selling or licensing copies, or posting to personal, institutional or third party websites are prohibited.

In most cases authors are permitted to post their version of the article (e.g. in Word or Tex form) to their personal website or institutional repository. Authors requiring further information regarding Elsevier's archiving and manuscript policies are encouraged to visit:

http://www.elsevier.com/authorsrights 


\title{
A nomenclatural note on Monanthesia and Bennettites
}

\author{
Gea Zijlstra ${ }^{\text {a,* }}$, Johanna H.A. van Konijnenburg-van Cittert ${ }^{\mathrm{a}, \mathrm{b}}$ \\ a Laboratory of Palaeobotany \& Palynology, Budapestlaan 4, 3584 CD Utrecht, The Netherlands \\ ${ }^{\mathrm{b}}$ Naturalis Biodiversity Center, Postbus 9517, 2300 RA Leiden, The Netherlands
}

\section{A R T I C L E I N F O}

\section{Article history:}

Received 19 December 2013

Received in revised form 13 January 2014

Accepted 19 January 2014

Available online 28 January 2014

\section{Keywords:}

Nomenclature

Monanthesia

Bennettites

Cycadeoidea

\section{A B S T R A C T}

This is a short nomenclatural note on the place of publication of Monanthesia and the lectotypification of Bennettites.

(C) 2014 Elsevier B.V. All rights reserved.
The name Monanthesia was introduced by Wieland (1934) for columnar bennettitalean stems with fructifications from the Upper Cretaceous of New Mexico (USA). In later years Monanthesia has also been described from the Lower and Upper Cretaceous of other parts of the world and additional species were recognized. However, the status of the name Monanthesia has long been a point of discussion, especially since Delevoryas (1959) regarded the name Monanthesia as invalidly published by Wieland (1934) and gave a new diagnosis. Most authors followed Delevoryas and refer to it as 'Monanthesia Wieland 1934 ex Delevoryas', e.g., Watson and Sincock (1992), Saiki and Yoshida (1999), Rothwell and Stockey (2002), and Watson and Lydon (2004). However, we are of a different opinion.

Our first conclusion is that Delevoryas cannot be considered to have validated this name, because he had four species of which he thought he validly published the new name/a new combination. All this is, however, without designation of the type of the generic name, thus not fulfilling Art. 40.1 and 40.6 of the Melbourne Code (McNeill et al., 2012).

Moreover, it does not appear to be necessary to start a search for the later validation of Monanthesia - thorough reading of Wieland's original publication revealed that this generic name was validly published in 1934 ! The only problem is that the generic diagnosis is not presented under a clear heading, but 'hidden' in the long text. On p. 94, Wieland (1934) gave a list of the occurrence "of Cycadeoids with flowers, fruits or flower-stalks in all the frond base axillae" (as such spaced by Wieland): six combinations in Cycadeoidea (occurring in N. America and Italy), followed by two in Monanthesia

\footnotetext{
* Corresponding author.

E-mail address: g.zijlstra@uu.nl (G. Zijlstra).
}

(M. blanca and M. magnifica from New Mexico). In the subsequent paragraph, this is stated: "The first six specimens ${ }^{1}$ of this remarkable group to be recovered are known only from single isolated occurrences. But the forms from New Mexico include a varied and splendid series now well under way of elaboration. ... In any case the cauliflorous types with fructifications in all frond axillae, have become a most imposing group, whether taken geographically, or geologically. Perhaps all the species should be included in some genus of convenience like the Monanthesia." Wieland was careful, placing in Monanthesia only the two species from New Mexico that were new and that he could well investigate: $M$. blanca and $M$. magnifica. In his textfig. 20 (to p. 115), a photograph of M. magnifica is given: a tangent section from the midregion of a columnar trunk. In the third paragraph of the caption an important sentence: "Separation from the genus Cycadeoidea rests only on the fruiting habitus." Yes: a flower in the axil of every leaf.

Delevoryas (1959) placed Monanthesia blanca in the synonymy of Monanthesia magnifica, and on p. 665 he published the combination in Monanthesia for three of the six Cycadeoidea species that Wieland listed on p. 94.

Bennettites Carruthers 1870 is the most important synonym of Cycadeoidea Buckland ex Lindl. et Hutton 1832. Soon after Seward's conclusion (Seward, 1917, p. 367-386) that these genera are inseparable, the use of Bennettites stopped. This was a conclusion without type designation. In our search for the lectotype of Bennettites, we could only find the mechanical choice of Andrews' Index (Andrews, 1955): the first of Carruthers' five species: Bennettites saxbyanus. Under Art. 10.5(b) of the Melbourne Code (McNeill et al., 2012) we reject this choice, because this species was transferred to Monanthesia by

\footnotetext{
${ }^{1}$ sic, specimens; we suppose species, each of which was represented by one specimen only.
} 
Watson and Lydon (2004), an action with which we agree. As lectotype for Bennettites we here designate Bennettites gibsonianus, the lectotype of which was well studied by Watson and Lydon (l.c. p. 17, Fig. 7A, B; England, Isle of Wight), who on p. 21 pointed out 'the enormous historical significance' of this 'exquisitely preserved type specimen'. Seward (1917, p. 386) transferred Bennettites gibsonianus to the genus Cycadeoidea as Cycadeoidea gibsoniana (Carruthers) Seward, and as such it is in use to date.

\section{References}

Andrews, H.N., 1955. Index of generic names of fossil plants 1820-1950. Bull. US Geol. Surv. 1013, 1-262.

Delevoryas, T., 1959. Investigations of North American cycadeoids: Monanthesia. Am. J. Bot. 46, 657-666.

McNeill, J., Barrie, F.R., Buck, W.R., Demoulin, V., Greuter, W., Hawksworth, D.L., Herendeen, P.S., Knapp, S., Marhold, K., Prado, J., Prud'homme van Reine,
W.F., Smith, G.F., Wiersema, J.H., Turland, N.J., 2012. International Code of Nomenclature for algae, fungi, and plants (Melbourne Code). Regnum Vegetabile 154 (ISBN 978-3-87429-425-6. See also http://www.iapt-taxon.org/ nomen/main.php).

Rothwell, G.W., Stockey, R.A., 2002. Anatomically preserved Cycadeoidea (Cycadeoideaceae), with a reevaluation of systematic characters for the seed cones of Bennettitales. Am. Bot. 89 (9), 1447-1458.

Saiki, K., Yoshida, Y., 1999. A new Bennettitalean trunk with unilacunar five-trace nodal structure from the Upper Cretaceous of Hokkaido, Japan. Am. J. Bot. 86 (3), 326-332.

Seward, A.C., 1917. Fossil Plants 3. Cambridge University Press, Cambridge 1-656 (pp. I-XVIII).

Watson, J., Lydon, S.J., 2004. The bennettitalean trunk genera Cycadeoidea and Monanthesia in the Purbeck, Wealden and Lower Greensand of southern England: a reassessment. Cretac. Res. 25, 1-26.

Watson, J., Sincock, J.A., 1992. Bennettitales of the English Wealden. Monogr. Palaeontol. Soc. 145 (588) ((for 1991), 228 pp., 23 pls.).

Wieland, G.R., 1934. Fossil cycads, with special reference to Raumeria reichenbachiana Goeppert sp. of the Zwinger of Dresden. Palaeontogr. Abt. B Paläophytologie 79, 85-130 (pls. 9-20). 